\title{
Advertising watchdog bans Kinder's online games and websites for children
}

Watchdog the Advertising Standards Authority (ASA) has upheld a complaint against confectionery firm Kinder which means the company has to stop targeting adverts to children via its Kindernauts website, Magic Kinder website, app and YouTube films.

The ASA upheld a complaint submitted by campaigning organisation the Children's Food Campaign.

The ruling ${ }^{1}$ by the ASA Council agreed that the sites and 'advergames' had broken rules set by the Committee of Advertising Practices (CAP) on the promotion of high fat, salt or sugar (HFSS) products to children under- 16 .

The Children's Food Campaign said the ruling set a ground-breaking precedent for future brand advertising and use of child-friendly cartoon characters and toys by confectionery, snacking or fast food companies, as the Kinder websites and advergames had created subbrands which heavily featured the toys and characters associated with Kinder Surprise chocolate products.

The ASA said in its ruling on Magic Kinder and Kindernauts that it was not possible to purchase Kinder Surprise toys separately from Kinder Surprise chocolate and considered they were an added incentive to purchase the product over other chocolate and confectionery products.

'We considered the toys were therefore intrinsically linked with the chocolate product and even young children would specifically associate the toys with the chocolate.'

The ASA has now instructed Ferrero, owner of the Kinder brand, to remove the advertising sites and games, and to avoid marketing directly to primary school children using child-friendly characters and promotional items such as toys.

The Kindernauts website, Magic Kinder advergames and YouTube channel are no longer available in the UK.

Children's Food Campaign Co-ordinator Barbara Crowther said: 'These web and app-based games and videos were deliberately designed to encourage children as young as three years old to collect the toys associated with Kinder chocolate. In the midst of a rising child obesity crisis, it's about time the ASA called time on these irresponsible marketing tactics, and we're delighted they upheld our complaint.'

Obesity Health Alliance Lead Caroline Cerny said: 'This is yet another example of the tactics industry use to encourage children to desire and ultimately consume their products.'

Dr Max Davie, Officer for Health Promotion for the Royal College of Paediatrics and Child Health (RCPCH), said: 'This is another

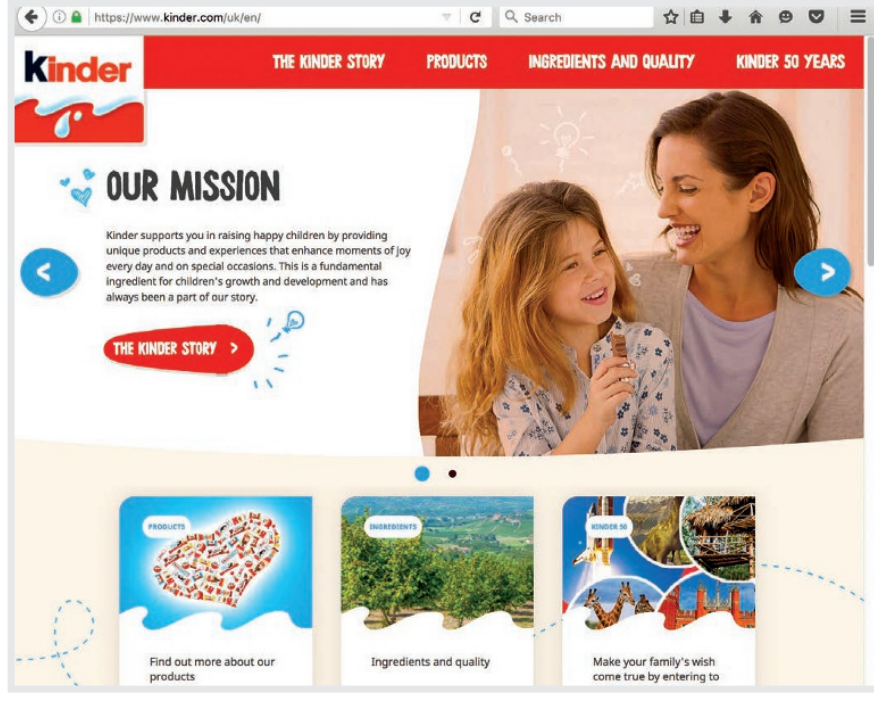

The Kindernauts website

example of food manufactures targeting impressionable children through advertising. Levels of severe obesity in children aged 10 to 11 years have reached the highest point since records began and it is these kinds of acts that contribute to these startling statistics.

'We hope to see Government go one step further and introduce restrictions which will protect children from harmful junk food marketing online and during on-demand services too.'

A Ferrero Spokesperson said: 'Ferrero has been working with the ASA in the UK on this issue to understand the concerns raised. Ferrero is committed to acting responsibly, which is why we aim all advertising and marketing communications for our products at adults not children. We firmly believe in parental choice and the role that parents play in choosing what is suitable for their own children.

'Magic Kinder was designed by a team of experts as a fun and educational app for families to use together. We have clear guidelines in place that ensure that there are no food products visible or referred to throughout the app.

'As a consequence of the ruling, Ferrero regrets that it has had to make the decision to temporarily suspend the app in the UK.'

1. Advertising Standards Authority. ASA Ruling on Ferrero UK Ltd t/a Kinder (19 September 2018). Available at https://www.asa.org.uk/rulings/ferrero-uk-Itd-a18-410956.html (accessed 24 September 2018).

\section{Are you a keen runner?}

Would you like run the 2019 London Marathon on behalf of dentists in need?

The BDA Benevolent Fund has one entry place up for grabs. For further information and to register your interest in the ballot please visit their website https://www.bdabenevolentfund.org.uk/get-i.../ london-marathon/ or get in touch via 02074864994.

The deadline for ballot submission is 26 October 2018 .

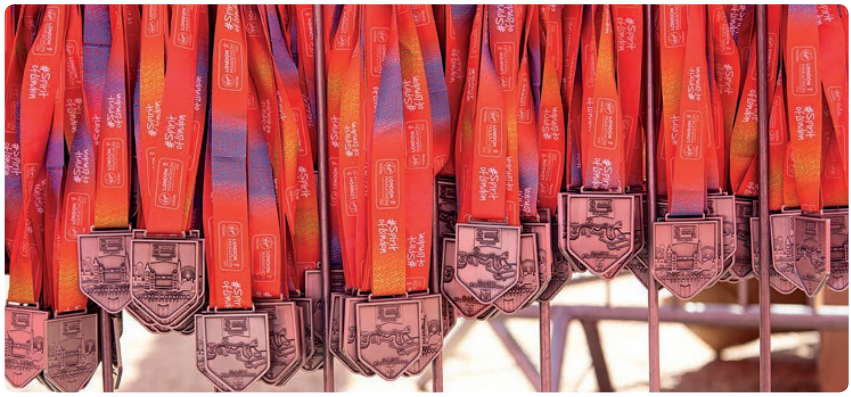

